\title{
Ferns and Lycophytes from fragments of semideciduous forest in central Espírito Santo, Brazil
}

\author{
Nelson Túlio Lage Pena ${ }^{1,3}$, Felipe Zamborlini Saiter ${ }^{1}$ \& Glória Maria de Farias Viégas-Aquije ${ }^{2}$
}

\begin{abstract}
This study presents a checklist of lycophytes and ferns from secondary semideciduous forests in São João de Petrópolis, Santa Teresa, Espírito Santo, Brazil. We recorded 37 species (four lycophytes and 33 ferns) belonging to nine families and 17 genera. Selaginella is the only genus representing lycophytes whereas Adiantum, Anemia and Asplenium are the main representative genera for ferns. Most species are lithophytes $(48.6 \%)$ or terrestrial $(21.6 \%)$. Epiphytes are scarce $(8.2 \%)$, and we did not record any arborescent, hemiepiphyte or scandent species. Climate seasonality, reduced size of forest fragments, and disturbance history may explain the low richness in the site. We recorded the occurrence of a regionally threatened fern species, namely, Asplenium austrobrasiliense, and revealed the first record of Asplenium otites in Espírito Santo. This demonstrates the biological relevance of semideciduous forest remnants in Espírito Santo and reinforces arguments for their effective protection.
\end{abstract}

Key words: Atlantic Forest, floristics, pteridophytes, secondary forest.

\section{Resumo}

Este estudo apresenta uma lista de licófitas e samambaias de florestas semidecíduas secundárias em São João de Petrópolis, Santa Teresa, Espírito Santo, Brasil. Registramos 37 espécies (quatro licófitas e 33 samambaias) pertencentes a nove famílias e 17 gêneros. Selaginella é o único gênero representando as licófitas, enquanto Adiantum, Anemia e Asplenium são os principais gêneros representativos de samambaias. A maioria das espécies são litófitas $(48,6 \%)$ ou terrestres $(21,6 \%)$. Epífitas são escassas $(8,2 \%)$ e não registramos nenhuma espécie arborescente, hemiepífita ou escandente. A sazonalidade climática, o tamanho reduzido dos fragmentos florestais e o histórico de perturbações podem explicar a baixa riqueza no local. Registramos a ocorrência de uma espécie de samambaia ameaçada regionalmente, a saber, Asplenium austrobrasiliense, e revelamos o primeiro registro de Asplenium otites no Espírito Santo. Isso demonstra a relevância biológica de remanescentes de floresta semidecídua no Espírito Santo e reforça os argumentos para a sua proteção efetiva.

Palavras-chave: Mata Atlântica, florística, pteridófitas, floresta secundária.

\section{Introduction}

Lycophytes and ferns are distinct clades of vascular plants, which account for around 12,000 species in the world (PPG I 2016). Most of these species are endemic to the Neotropics, a recognized diversity hotspot for both clades (Almeida \& Salino 2016). In Brazil, such clades comprise together more than 1,200 species, ca. $70 \%$ of them occurring in the Atlantic Forest domain (Prado et al. 2015). The Atlantic Forest has been recognized as a global biodiversity hotspot (Myers et al. 2000).
It is currently represented by forest fragments with reduced size (mostly $<100$ ha, according to Ribeiro et al. 2009), suffering further biological pauperization.

Despite the ever increasing amount of inventories of lycophytes and ferns in the Atlantic Forest over the last two decades, some regions of this phytogeographic domain remain poorly known. For instance, the inventories are relatively scarce in Espírito Santo, a region that is recognized by a high diversity of lycophytes and ferns (Prado

\footnotetext{
${ }^{1}$ Instituto Federal do Espírito Santo, Campus Santa Teresa, Rod. ES-080, Km 93, 29660-000, São João de Petrópolis, Santa Teresa, ES, Brazil.

${ }^{2}$ Instituto Federal do Espírito Santo, Campus Vila Velha, Av. Ministro Salgado Filho 1000, 29106-210, Soteco, Vila Velha, ES, Brazil.

${ }^{3}$ Author for correspondence: penatulio@gmail.com
} 
et al. 2015). There, inventories have been carried out in just a few well preserved areas, such as parks and reserves (e.g., Behar \& Viégas 1992; Behar \& Viégas 1993; Viégas-Aquije \& Flausino 2007; Andrade et al. 2016; Sylvestre et al. 2016; Schwartsburd et al. 2017). However, it is known that the Atlantic Forest is mostly represented by secondary forests that can host an important fraction of the original flora and reveal useful pieces of information for taxonomic, ecologic and biogeographic studies (Ribeiro et al. 2009).

In this paper, we present a checklist of lycophytes and ferns that occur in secondary forests in São João de Petrópolis, Santa Teresa, Espírito Santo. This study is the first report of these plant groups in semideciduous forests in Espírito Santo and takes part in the efforts for inventorying the flora in the lower Rio Santa Maria do Doce basin, a highly disturbed region where several new, endemic angiosperm species have been surprisingly recorded in the last 20 years (e.g., Assis 2003; Coelho et al. 2006; Leme et al. 2010; Pirani et al. 2011). We not only expect to improve the knowledge about lycophytes and ferns in such an important region, but also support studies on plant diversity and conservation decisions in the Atlantic Forest hotspot.

\section{Material and Methods}

\section{Study area}

São João de Petrópolis (SJP) is a district of the municipality of Santa Teresa, located in the central area of the state of Espírito Santo, Brazil (Fig. 1). According to Climate-Data's database (<https://pt.climate-data.org/>), the climate is typically warm and seasonally humid, with a dry season occurring from May to September. The average annual temperature is $24.4^{\circ} \mathrm{C}$ and the average annual precipitation is $1161 \mathrm{~mm}$. The relief is hilly and the elevation varies from 150 to $500 \mathrm{~m}$. The lower areas comprise a flat, wide valley, which is crossed by the Rio Santa Maria do Doce. This valley is occupied by agricultural fields, houses, roads, and the buildings and facilities of the Instituto Federal do Espírito Santo. The hills around the valley are commonly covered by interspersed
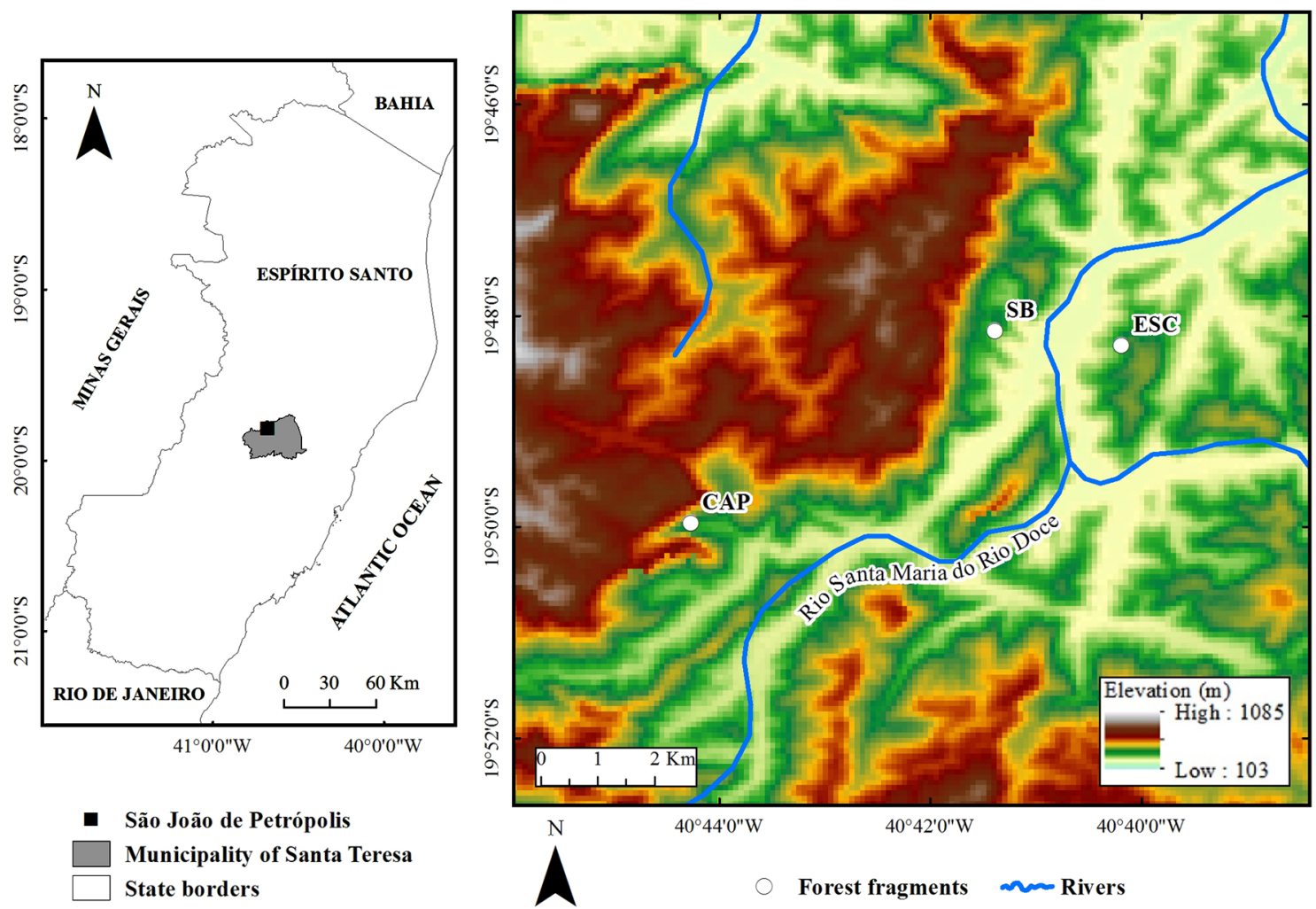

Figure 1 - Location map of São João de Petrópolis in Santa Teresa, central Espírito Santo, Brazil. Forest fragments included in this study are represented by white circles. $(\mathrm{CAP}=$ Fazenda Capeletti; $\mathrm{SB}=$ Mata do São Brás; $\mathrm{ESC}=\mathrm{Mata}$ da Escola). 
secondary forests with rocky outcrops (Fig. 2a,b). In some of these hills there are narrow, rocky streams, usually intermittent during the dry season (Fig. 2c). The vegetation is composed of broadleaved seasonal semideciduous forests of lower or upper plains, according to OliveiraFilho (2009).

\section{Data collection and analysis}

We collected vouchers of lycophytes and ferns bi-monthly in three forest fragments (Fig. 1) from March 2012 to May 2013. Two of these fragments, named Mata do São Brás (SB; ca. 50 ha; 19'48'09'S, 40'41'23' W) and Mata da Escola (ESC; ca. 170 ha; 1948'17"S, 4040'11"W), occupy opposite sides of the Rio Santa Maria do Doce valley, within the farm of the Instituto Federal do Espírito Santo. The third fragment is located in the Fazenda Capeletti (CAP; ca. 20 ha; 1949'58'S, $\left.40^{\circ} 44^{\prime} 16^{\prime \prime} \mathrm{W}\right)$. All specimens were prepared according to methods for the botanical collection, which were proposed by Windisch (1992), and then incorporated into the herbarium of the Instituto Nacional da Mata Atlântica (MBML). We consulted taxonomic monographs and the collections of the Herbarium MBML, as well as the herbarium of the Universidade Federal do Espírito Santo (VIES), for the determination of specimens.

The checklist was supplemented with a few species whose occurrence in SJP can be attested by previously deposited specimens in the Herbarium MBML. We adopted the PPG I's (2016) classification for ferns and lycophytes. Species names and authors were confirmed through the consultation of the IPNI ( $<$ http://www.ipni.org $>$ ). Furthermore, we indicate the life form (terrestrial, lithophyte, or epiphyte) for each species.

\section{Results}

The final checklist comprises 37 species, four of which are lycophytes and 33 are ferns (Tab. 1; Figs. 3-5). Mata do São Brás (SB), Mata da Escola (ESC), and Fazenda Capeletti (CAP) show, respectively, 19, 13, and 15 species. All lycophytes are in the genus Selaginella P.Beauv. (Selaginellaceae), and they were exclusively collected on either rocks or shallow soils along intermittent streams within SB and CAP. On the
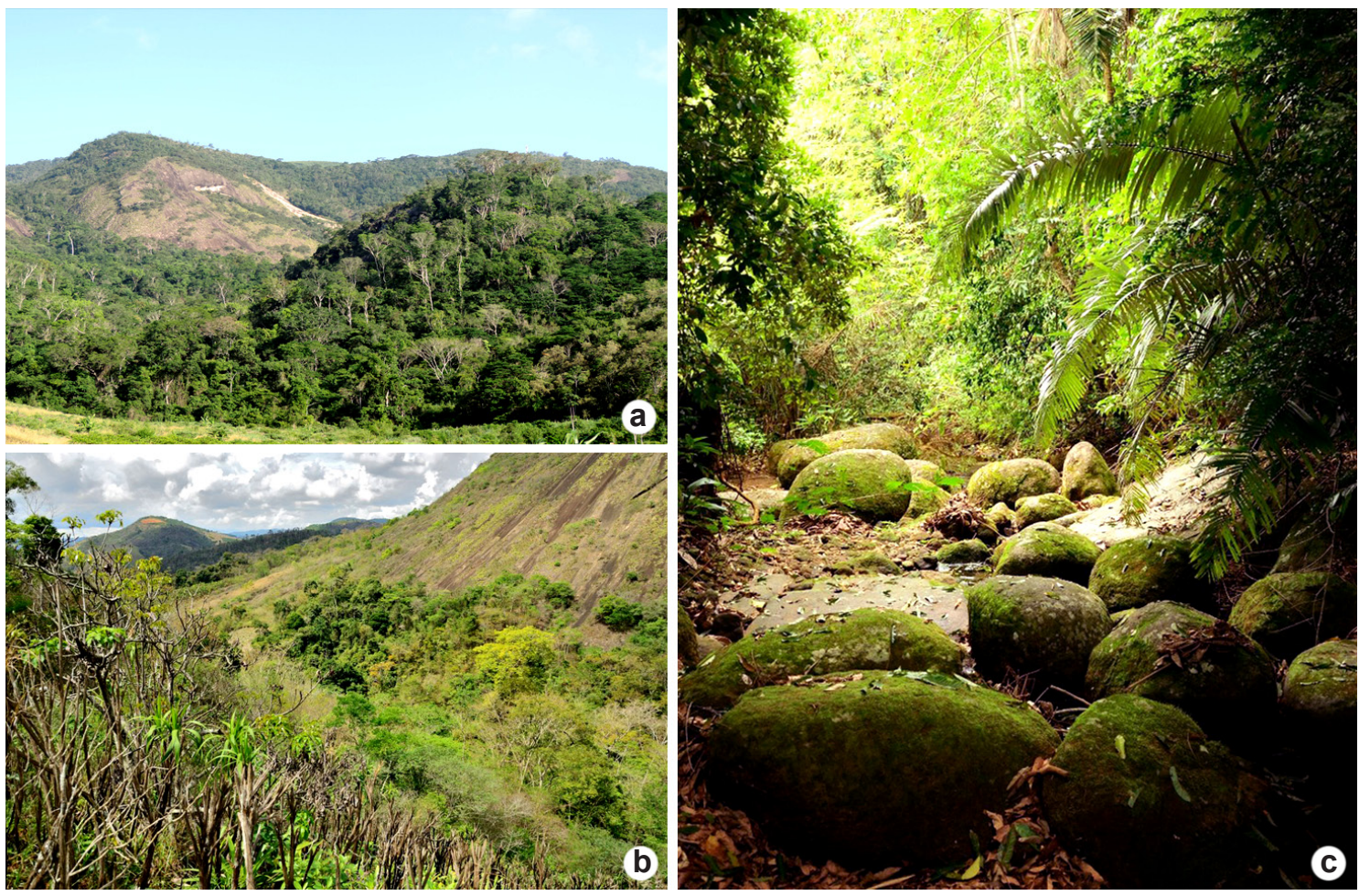

Figure 2 - Images from São João de Petrópolis forests - a. Mata do São Brás; b. Interspersed secondary forests with rocky outcrops in Fazenda Capeletti; c. Intermittent rocky stream within Mata do São Brás. 
Table 1 - Lycophytes and ferns recorded in three forest fragments in São João de Petrópolis, Santa Teresa, central Espírito Santo, Brazil. Life forms: $\mathrm{LT}=$ lithophytes; $\mathrm{TR}=$ terrestrial; $\mathrm{EP}=$ epiphytes. Forest fragments: $\mathrm{SB}=\mathrm{Mata}$ do São Brás; ESC = Mata da Escola; CAP = Fazenda Capeletti.

\begin{tabular}{|c|c|c|c|}
\hline & & & Forest fragments \\
\hline Taxa & Life form & Voucher & SB ESC CAP \\
\hline
\end{tabular}

\section{Selaginellaceae Willk.}

Selaginella flexuosa Spring

Selaginella convoluta (Arn.) Spring

Selaginella muscosa Spring

Selaginella sulcata (Desv.) Spring ex Mart.

Anemiaceae Link

Anemia collina Raddi

Anemia hirsuta (L.) Sw.

Anemia rotundifolia Schrad.

Anemia tomentosa (Sav.) Sw.

\section{Aspleniaceae Newman}

Asplenium austrobrasiliense (Christ) Maxon

Asplenium otites Link

Asplenium pulchellum Raddi

Asplenium serratum L.

\section{Blechnaceae Newman}

Blechnum lanceola Sw.

Blechnum occidentale L.

Neoblechnum brasiliense (Desv.) Gasper \& V.A.O.Dittrich

\section{Dryopteridaceae Herter}

Ctenitis falciculata (Raddi) Ching

Parapolystichum acutum (Kuntze) Labiak, Sundue \& R.C.Moran

Lygodiaceae M.Roem.

Lygodium volubile $\mathrm{Sw}$.

Polypodiaceae J.Presl

Campyloneurum nitidum (Kaulf.) C. Presl

Microgramma vacciniifolia (Langsd. \& Fisch.) Copel.

Pecluma plumula (Humb. \& Bonpl. ex Willd.) M.G. Price

Pecluma filicula (Kaulf.) M.G.Price

Pteridaceae E.D.M.Kirchn.

Adiantum rhizophytum Schrad.

Adiantum curvatum Kaulf.

Adiantum deflectens Mart.

Adiantum obliquum Willd.

Adiantum pulverulentum $\mathrm{L}$.

Adiantopsis radiata (L.) Fée

\begin{tabular}{|c|c|c|c|}
\hline $\mathrm{LT} / \mathrm{TR}$ & N.T.L.Pena 39 & & \\
\hline LT & N.T.L.Pena 66 & $\mathrm{X}$ & \\
\hline LT & N.T.L.Pena 84 & $\mathrm{X}$ & \\
\hline LT & N.T.L.Pena 65 & $X$ & \\
\hline LT & N.T.L.Pena 40 & & \\
\hline TR & N.T.L.Pena 92 & $X$ & \\
\hline $\mathrm{LT} / \mathrm{TR}$ & N.T.L.Pena 25 & & $\mathrm{X}$ \\
\hline $\mathrm{LT} / \mathrm{TR}$ & N.T.L.Pena 87 & $\mathrm{X}$ & \\
\hline
\end{tabular}

$\begin{array}{lllll}\text { LT } & \text { N.T.L.Pena } 70 & \text { X } & & \\ \text { LT } & \text { N.T.L.Pena } 60 & \text { X } & & \text { X } \\ \text { LT } & \text { N.T.L.Pena } 64 & \text { X } & & \\ \text { LT } & \text { W.Boone } 598 & & \text { X } & \end{array}$

$\begin{array}{ccccc}\text { LT } & \text { N.T.L.Pena } 85 & \text { X } & & \text { X } \\ \text { LT/TR } & \text { N.T.L.Pena 78 } & \text { X } & \text { X } & \text { X } \\ \text { LT/TR } & \text { N.T.L.Pena } 90 & \text { X } & & \end{array}$

$\begin{array}{lll}\text { TR } & \text { N.T.L.Pena } 67 & \text { X } \\ \text { LT } & \text { N.T.L.Pena } 53 & \end{array}$

EP R.P.Oliveira $861 \quad X$

EP A.P.Fontana $223 \quad X$

EP A.P.Fontana $224 \quad X$

LT N.T.L.Pena $50 \quad X$

LT N.T.L.Pena 57 X

\begin{tabular}{ccccc} 
TR & N.T.L.Pena 37 & & X & \\
TR & N.T.L.Pena 80 & X & X & \\
LT/TR & N.T.L.Pena 33 & & X & \\
LT & N.T.L.Pena 76 & X & & \\
TR & N.T.L.Pena 86 & X & X & X \\
LT/TR & N.T.L.Pena 34 & & X & \\
\hline
\end{tabular}




\begin{tabular}{|c|c|c|c|c|c|}
\hline \multirow{2}{*}{ Taxa } & \multirow{2}{*}{ Life form } & \multirow{2}{*}{ Voucher } & \multicolumn{3}{|c|}{ Forest fragments } \\
\hline & & & SB & ESC & CAP \\
\hline Cheilanthes eriophora (Fée) Mett. & LT & $\begin{array}{l}\text { H.Q.Boudet } \\
\text { Fernandes } 1722\end{array}$ & & $\mathrm{X}$ & \\
\hline Cheilanthes goyazensis (Taub.) Domin & LT & N.T.L.Pena 47 & & & $\mathrm{X}$ \\
\hline Doryopteris collina (Raddi) J.Sm. & LT & N.T.L.Pena 45 & & & $\mathrm{X}$ \\
\hline Doryopteris varians (Raddi) J.Sm. & LT & N.T.L.Pena 51 & & & $\mathrm{X}$ \\
\hline Hemionitis tomentosa (Lam.) Raddi & TR & N.T.L.Pena 75 & $\mathrm{X}$ & & \\
\hline Pteris denticulata $\mathrm{Sw}$. & TR & N.T.L.Pena 88 & $\mathrm{X}$ & $\mathrm{X}$ & \\
\hline Pteris leptophylla $\mathrm{Sw}$. & LT & N.T.L.Pena 54 & & & $X$ \\
\hline \multicolumn{6}{|l|}{ Thelypteridaceae Pic.Serm. } \\
\hline Christella dentata (Forssk.) Brownsey \& Jermy & $\mathrm{LT} / \mathrm{TR}$ & N.T.L.Pena 79 & $\mathrm{X}$ & & \\
\hline Christella hispidula (Decne.) Holttum & TR & N.T.L.Pena 91 & $\mathrm{X}$ & & \\
\hline
\end{tabular}

other hand, the fern species belong to eight families and 16 genera. The most representative fern family is Pteridaceae (13 spp.), and the most representative fern genera are Adiantum L. (five spp.), Anemia Sw., and Asplenium L. (four spp. each).

The most common life forms are lithophytes $(48.6 \%)$ and terrestrial $(21.6 \%)$. Some species $(21.6 \%)$ present these two life forms, and only three species are epiphytes $(8.2 \%)$. We did not record any arborescent, hemiepiphytic or scandent species. The fern species Asplenium serratum L., Campyloneurum nitidum (Kaulf.) C.Presl, Cheilanthes eriophora (Fée) Mett., Lygodium volubile Sw. and Microgramma vacciniifolia (Langsd. \& Fisch.) Copel. were incorporated into the checklist due to the existence of specimens that were previously collected in SJP and deposited in the Herbarium MBML.

The fern species Asplenium otites Link (Fig. $4 \mathrm{~g}$ ) was reported for the first time in Espírito Santo. In turn, Blechnum lanceola Sw. (Fig. 3g) had only been recorded once in Espírito Santo before our study (in Pontões Capixabas, northwestern of the state, according to Dittrich et al. 2015). Among the species recorded here, only Asplenium austrobrasiliense (Christ) Maxon (Fig. 5) is considered a threatened fern species in Espírito Santo (Simonelli \& Fraga 2007).

\section{Discussion}

The checklist presented here indicates that SJP forests are not as rich in terms of lycophytes and ferns as some forest sites within the Atlantic Forest domain. For instance, Melo \& Salino (2002) recorded 123 species in a semideciduous forest in the Parque Estadual do Rio Doce, eastern Minas Gerais, Viégas-Aquije \& Flausino (2007) found 126 species in an evergreen forest in the Reserva Biológica Augusto Ruschi, central Espírito Santo, Matos et al. (2010) collected 182 species in a rain forest in Serra Bonita, eastern Bahia, and Mazziero et al. (2015) recorded 235 species in a rain forest in the Parque Estadual Turístico do Alto Ribeira, southern São Paulo.

Three complementary suppositions help to explain the low richness in SJP forests. First, seasonal forests, such as those in SJP, commonly support less plant species than rain forests in the Atlantic Forest domain due to physiological and reproductive constraints caused by the low water availability during dry periods (Oliveira-Filho \& Fontes 2000). Second, larger forest fragments can support more species than smaller ones (Fahrig 2003). In this sense, SJP forest fragments, even accounting together ca. 250 ha, certainly cannot have as many species as those remnants from the aforementioned studies (all of them with 2000 ha or more). Third, disturbance history directly affects the local diversity of plants (Chazdon 2003). In fact, SJP forests were, in part, selectively logged and burned down in the past. As a consequence, some species of lycophytes and ferns from the original flora may have been extinct in those areas. Both the scarcity of epiphyte species and the absence of arborescent, hemiepiphyte and scandent species in our checklist may represent negative effect of disturbances on the local diversity of plants. Usually, such life forms are better represented in 

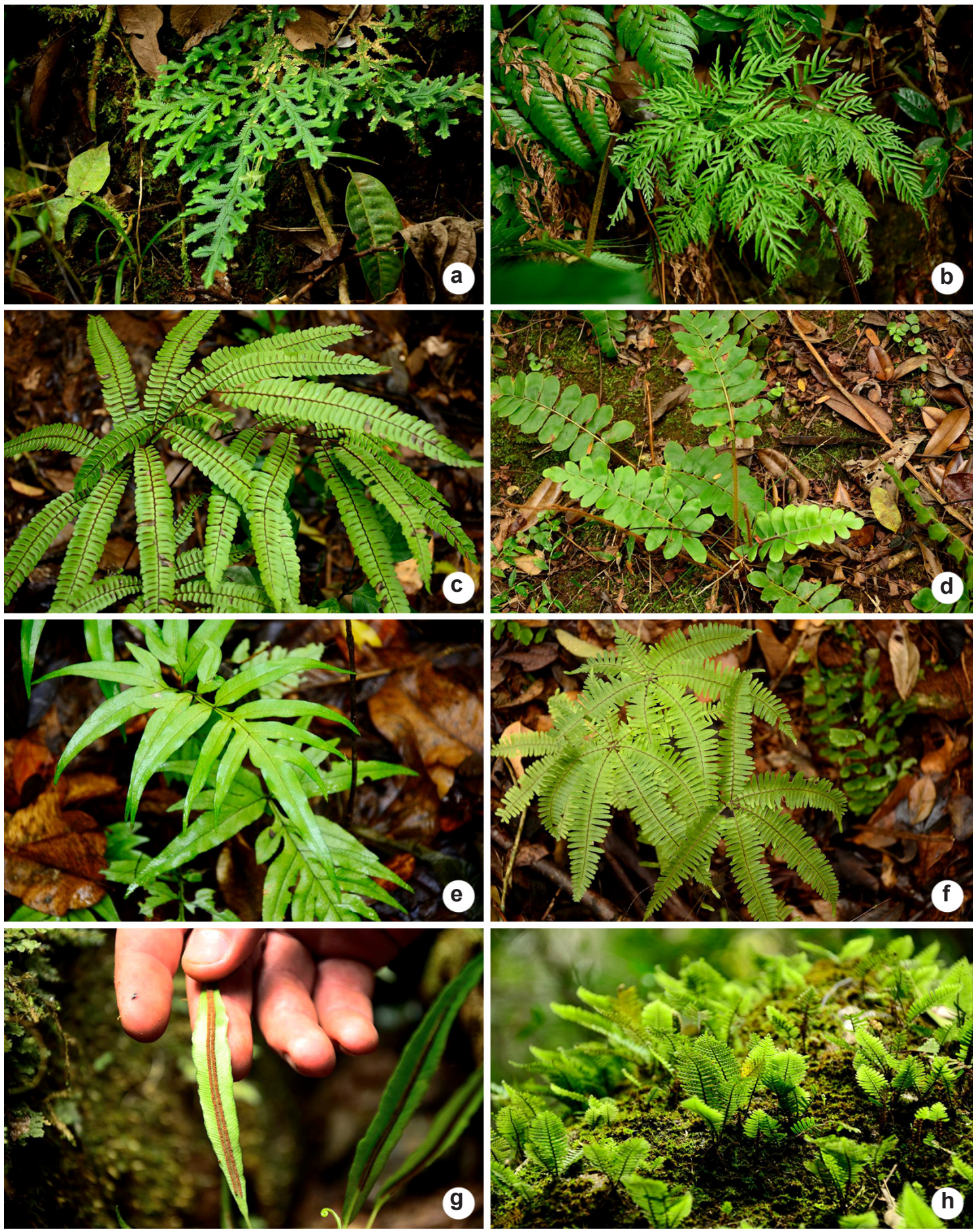

Figure 3 - Some fern species collected in São João de Petrópolis, Santa Teresa, central Espírito Santo, Brazil - a. Selaginella flexuosa (Selaginellaceae). b. Pteris leptophylla (Pteridaceae). c. Adiantum pulverulentum (Pteridaceae). d. Anemia collina (Anemiaceae). e. Pteris denticulata (Pteridaceae). f. Adiantopsis radiata (Pteridaceae). g. Blechnum lanceola (Blechnaceae). h. Pecluma filicula (Polypodiaceae). 

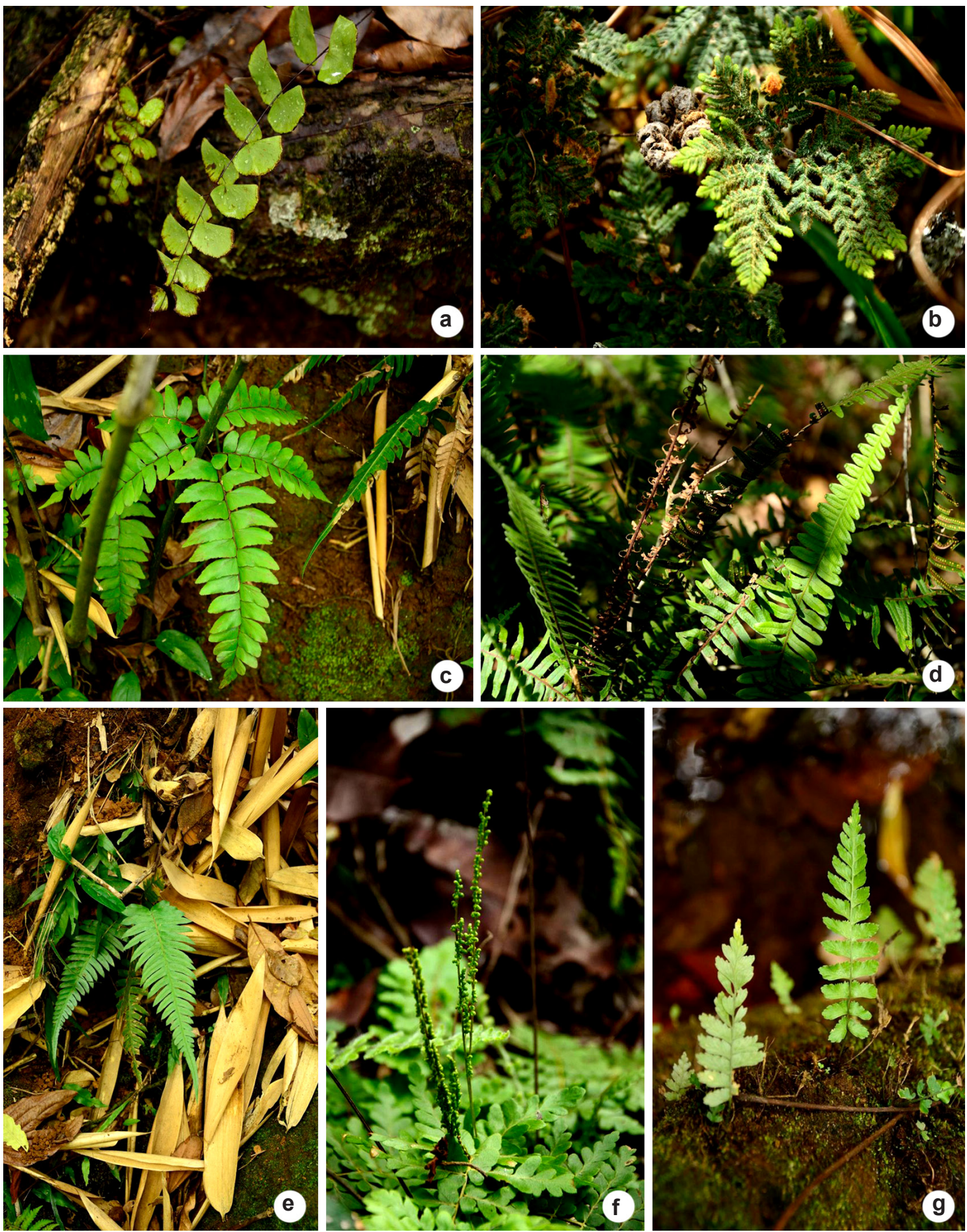

Figure 4 - Some fern species collected in São João de Petrópolis, Santa Teresa, central Espírito Santo, Brazil - a. Adiantum deflectens (Pteridaceae). b. Cheilanthes goyazensis (Pteridaceae). c. Adiantum obliquum (Pteridaceae). d. Pecluma plumula (Polypodiaceae). e. Blechnum occidentale (Blechnaceae). f. Anemia tomentosa (Anemiaceae). g. Asplenium otites (Aspleniaceae). 

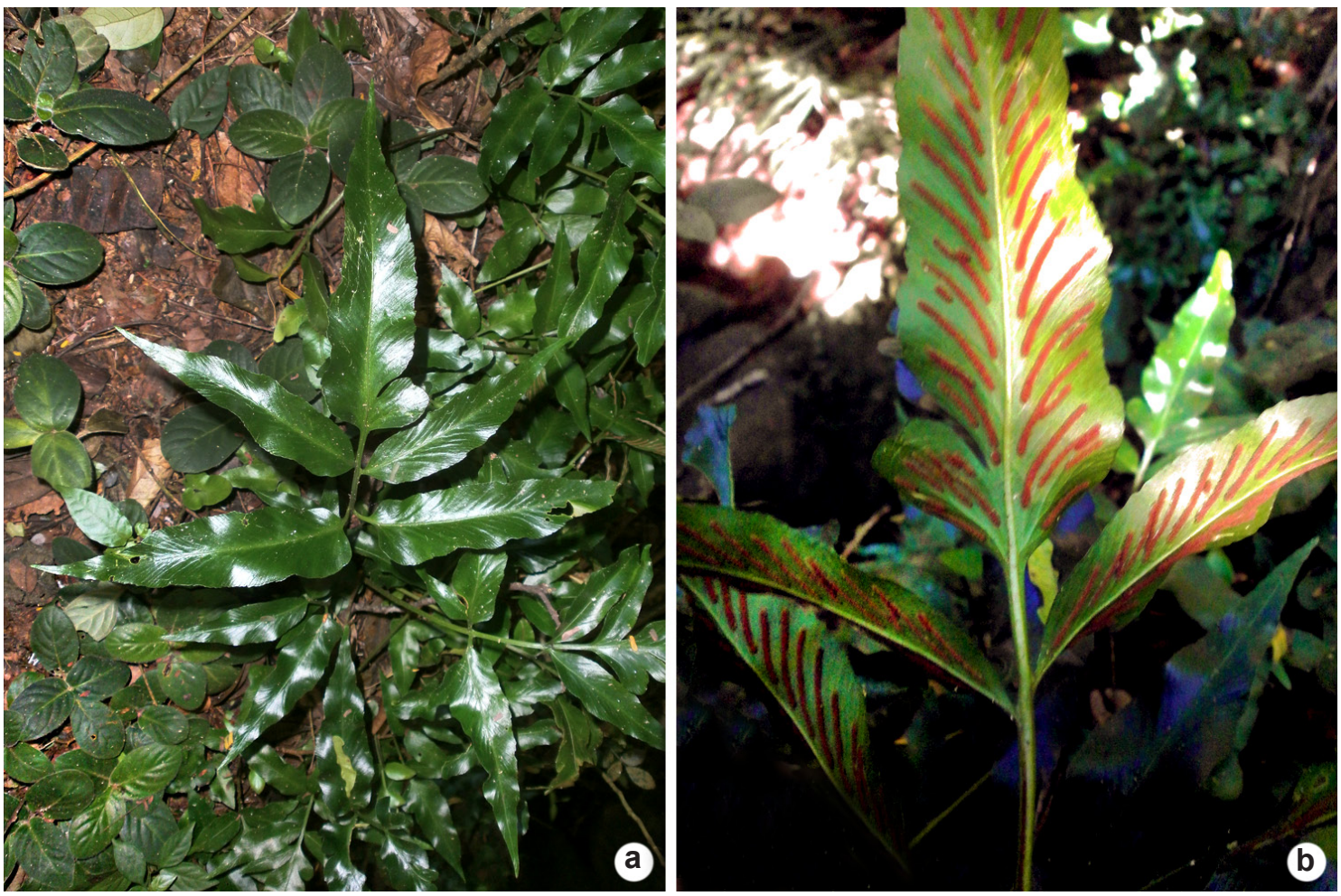

Figure 5 - Asplenium austrobrasiliense (Aspleniaceae), a threatened fern species in Espírito Santo - a. adaxial surface of laminae; b. abaxial surface of laminae.

well preserved sites across the Atlantic Forest, even in semideciduous forests (e.g., Melo \& Salino 2002; Matos et al. 2010; Mazziero et al. 2015).

In contrast, past disturbances may have led to an increase of the density of the disturbancetolerant species (i.e., species which tolerate both low humidity and high light intensity). In fact, some species reported here are typically known as being found in disturbed sites, such as Adiantum pulverulentum L. (Fig. 3c), Anemia rotundifolia Schrad, Pteris denticulata Sw. (Fig. 3e), and the alien species Christella dentata (Forssk.) Brownsey \& Jermy (see Colli et al. 2004; Schwartsburd \& Labiak 2007; Gasper \& Sevegnani 2010 for comments on some of those species).

Considering a regional approach, the SJP forests notably host populations of either threatened fern species (A. austrobrasiliense) or few collected ones (A. otites and $B$. lanceola). This corroborates recent insights about the biological relevance of semideciduous forest in Espírito Santo (for instance, see Abreu et al. 2013; Saiter et al. 2015), and reinforces arguments for the creation of parks and reserves in such a forest type (Simonelli \&
Fraga 2007). Given that there are only four small reserves covered by semideciduous forests across Espírito Santo (Simonelli \& Fraga 2007), the Parque Estadual Cachoeira da Fumaça (ca. 160 ha), Parque Estadual Mata das Flores (800 ha), Floresta Nacional de Pacotuba (ca. 450 ha) and Reserva Particular do Patrimônio Natural Cafundó (517 ha), we argue that the protection of such forests is still insufficient. Therefore, the checklist presented here not only enriches the knowledge about ferns and lycophytes in Espírito Santo, but also offers useful information for conservation planning in the Atlantic Forest hotspot.

\section{Acknowledgements}

We thank Josiene Rossini and Joelcio Freitas for contribution in laboratory work; Rodrigo Borçato for photographs, Lana Sylvestre, Alexandre Salino and Thaís E. Almeida for support in specimens identification; Elton John de Lírio, Jackson Gurtler, Monique Perini and Wellinton de Queiróz Prates for help in field work; and the Instituto Nacional da Mata Atlântica for permission of using data and equipments of the Herbarium 
MBML. N.T.L. Pena also thanks the Fundação de Amparo à Pesquisa do Espírito Santo and Instituto Federal do Espírito Santo for the grant Pibic/PE632.

\section{References}

Abreu KMP, Silva GF \& Silva AG (2013) Análise fitossociológica da Floresta Nacional de Pacotuba, Cachoeiro de Itapemirim, ES, Brasil. Cerne 19: 157-168.

Almeida TE \& Salino A (2016) State of the art and perspectives on neotropical fern and lycophyte systematics. Journal of Systematics and Evolution 54: 679-690.

Andrade RC, Sylvestre LS \& Menezes LFT (2016) Ferns and lycophytes in three fragments of Tabuleiro lowland forest in northern Espírito Santo state, Brazil: composition and floristic relationships in Atlantic forest. Brazilian Journal of Botany 39: 1-11.

Assis MC (2003) Duas novas espécies de Alstroemeria L. (Alstroemeriaceae) para o Brasil. Acta Botanica Brasilica 17: 179-182.

Behar L \& Viégas GMF (1992) Pteridophyta da Restinga do Parque Estadual de Setiba, ES. Vol. 1. Nova Série. Boletim do Museu de Biologia Professor Mello Leitão, Santa Teresa. Pp. 39-59.

Behar L \& Viégas GMF (1993) Pteridophyta da Restinga de Comboios, Aracruz/Linhares, ES. In: III Simpósio de Ecossistemas da Costa Brasileira. Vol. 3. ACIESP, São Paulo. Pp. 134-144.

Chazdon RL (2003) Tropical forest recovery: legacies of human impact and natural disturbances. Perspectives in Plant Ecology, Evolution and Systematics 6: 51-71.

Climate-Data.Org (2017) Dados climáticos para cidades mundiais. Available at <https:// pt.climate-data.org/>. Access on 30 May 2017.

Coelho MAN (2006) New espécies of Anthurium (Araceae) from Brazil. Aroideana 29: 91-103.

Colli AMT, Salino A, Souza SA, Lucca ALT \& Silva RT (2004) Pteridófita do Parque Estadual da Vussununga, Santa Rita do Passa Quatro (SP), Brasil. Capetinga Leste e Capetinga Oeste. Revista do Instituto Florestal 16: 25-30.

Dittrich VAO, Salino A \& Monteiro R (2015) The Blechnum occidentale (Blechnaceae, Polypodiopsida) species group in southern and southeastern Brazil. Phytotaxa 231: 201-229.

Fahrig L (2003) Effects of Habitat Fragmentation on Biodiversity. Annual Review of Ecology, Evolution, and Systematics 34: 487-515.

Gasper AL \& Sevegnani L (2010) Lycophyta e samambaias do Parque Nacional da Serra do Itajaí, Vale do Itajaí, SC, Brasil. Hoehnea 37: 755-767.
IPNI - The International Plant Names Index (2017) Available at $<$ http://www.ipni.org/ipni/>. Access on 30 May 2017.

Leme EMC, Fraga CN, Kollmann LJC, Brown GK, Till W, Ribeiro OBC, Machado MC, Monteiro FJS \& Fontana AP (2010) Miscellaneous new species in the Brazilian Bromeliaceae. Rodriguésia 61: 21-67.

Matos FB, Amorim AM \& Labiak PH (2010) The ferns and lycophytes of a montane tropical forest in southern Bahia, Brazil. Journal of the Botanical Research Institute of Texas 4: 333-346.

Mazziero FFF, Labiak PH \& Paciencia MLB (2015) Checklist of ferns and lycophytes from the Parque Estadual Turístico do Alto Ribeira, Iporanga, São Paulo, Brazil. Check List 11: 1-9.

Melo LCN \& Salino A (2002) Pteridófitas de duas áreas de floresta da Bacia do Rio Doce no estado de Minas Gerais, Brasil. Lundiana 3: 129-139.

Myers N, Mittermeier RA, Mittermeier CG, Fonseca GAB \& Kent J (2000) Biodiversity hotspots for conservation priorities. Nature 403: 853-858.

Oliveira-Filho AT (2009) Classificação das fitofisionomias da América do Sul cisandina tropical e subtropical: proposta de um novo sistema - prático e flexível - ou uma injeção a mais de caos? Rodriguésia 60: 237-258.

Oliveira-Filho AT \& Fontes MAL (2000) Patterns of floristic differentiation among Atlantic forests in southeastern Brazil and the influence of climate. Biotropica 32: 793-810.

Pirani JR, Groppo M \& Kallunki JA (2011) Two new species and a new combination in Conchocarpus (Rutaceae, Galipeeae) from eastern Brazil. Kew Bulletin 66: 521-527.

PPG I - Pteridophyte Phylogeny Group (2016) A community-derived classification for extant lycophytes and ferns. Journal of Systematics and Evolution 54: 563-603.

Prado J, Sylvestre L, Labiak PH, Windisch PG, Salino A, Barros ICL, Hirai RY, Almeida TE, Santiago ACP, Kieling-Rubio MA, Pereira AFN, Øllgaard B, Ramos CGV, Mickel JT, Dittrich VAO, Myssen CM, Schwartsburd PB, Condack JPS, Pereira JBS \& Matos FB (2015) Diversity of ferns and lycophytes in Brazil. Rodriguésia 66: 1073-1083.

Ribeiro MC, Metzger JP, Martensen AC, Ponzoni FJ \& Hirota MM (2009) The Brazilian Atlantic Forest: how much is left, and how is the remaining forest distributed? Implications for conservation. Biological Conservation 142: 1141-1153.

Saiter FZ, Eisenlohr PV, França GS, Stehmann JR, Thomas WW \& Oliveira-Filho AT (2015) Floristic units and their predictors unveiled in part of the Atlantic Forest hotspot: implications for conservation planning. Anais da Academia Brasileira de Ciências 87: 2031-2046. 
Schwartsburd PB \& Labiak PH (2007) Pteridófitas do Parque Estadual de Vila Velha, Ponta Grossa, Paraná, Brasil. Hoehnea 34: 159-209.

Schwartsburd PB, Miranda CV, Pena NTL, Oliveira MH, Silva RV, Marcolino F (2017) Checklist of ferns and lycophytes from Parque Estadual Mata das Flores, Castelo, Espírito Santo, Brazil. Check List 13: 621-633.

Simonelli M \& Fraga CN (2007) Espécies da flora ameaçadas de extinção no estado do Espírito Santo. IPEMA, Vitória. 146p.

Sylvestre LS, Almeida TE, Mynssen CM \& Salino A (2016) Samambaias e licófitas da Reserva Natural
Vale, Linhares, ES. In: Rolim SG, Menezes LFT \& Srbek-Araújo AC (eds) Floresta Atlântica de Tabuleiro: diversidade e endemismos na Reserva Natural Vale. Ed. Rupestre, Belo Horizonte. Pp. 157-166.

Viégas-Aquije GMF \& Flausino IKS (2007) Levantamento florístico de pteridófitas da Reserva Biológica Augusto Ruschi, Santa Teresa, ES. Revista Brasileira de Biociência 5: 909-911.

Windisch PG (1992) Pteridófitas da região Norteocidental do estado de São Paulo: guia para estudo e excursões. 2 ${ }^{\mathrm{a}}$ ed. Universidade Estadual Paulista, São José do Rio Preto. 110p. 